\title{
Increase of the 40,000-mol wt Pertussis Toxin Substrate (G protein) in the Failing Human Heart
}

\author{
Arthur M. Feldman, Andree E. Cates, William B. Veazey, Ray E. Hershberger, Michael R. Bristow, \\ Kenneth L. Baughman, William A. Baumgartner, and Cornelis Van Dop \\ Departments of Medicine, Cardiovascular Surgery, and Pediatrics, The Johns Hopkins University School of Medicine, Baltimore, \\ Maryland 21205; and Department of Medicine, University of Utah School of Medicine, Salt Lake City, Utah 84132
}

\begin{abstract}
Human heart failure is associated with a diminished contractile response to $\beta$-adrenergic agonists. We hypothesized that alterations in the activity of a guanine nucleotide-binding regulatory protein ( $G$ protein) might be partially responsible for this abnormality. We therefore measured the activity of $G$ proteins in failing human myocardium utilizing bacterial toxin-catalyzed ADP ribosylation. The activity of a $40,000-\mathrm{mol}$ wt pertussis toxin substrate $\left(\alpha \mathrm{G}_{40}\right)$ was increased by $36 \%$ in failing human hearts when compared with nonfailing controls. In contrast, there was no change in the level of the stimulatory regulatory subunit $\left(G_{8}\right)$. The increased activity in $\alpha G_{40}$ was associated with a $30 \%$ decrease in basal as well as 5 -guanylyl imidodiphosphate-stimulated adenylate cyclase activity. These data suggest that increased $\alpha G_{40}$ activity is a new marker for failing myocardium and may account at least in part for the diminished responsiveness to $\beta_{1}$-adrenergic agonists in the failing human heart.
\end{abstract}

\section{Introduction}

Human heart failure is associated with a diminished contractile response to $\beta$-adrenergic agonists (1). Bristow et al. $(2,3)$ demonstrated downregulation of the $\beta_{1}$-adrenergic receptors and subsensitivity of $\beta$-adrenergic responses in failing human hearts. However, another study (4) suggested that human heart failure may be associated with a more global abnormality in the production of the second messenger cyclic AMP by the receptor-adenylate cyclase complex that is independent of adrenergic receptor downregulation.

The hormone receptor-adenylate cyclase system consists of three functionally distinct, membrane-bound proteins: (a) hormone receptors, (b) catalytic adenylate cyclase which synthesizes the intracellular second messenger cyclic AMP, and (c) various guanine nucleotide-binding regulatory proteins which stimulate $\left(G_{s}\right)$ or inhibit $\left(G_{i}\right)$ the catalytic subunit $(5)$. Pharmacologic studies of membranes from failing human hearts using fluoride or forskolin, which are selective activators

Dr. Van Dop's current address is Howard Hughes Medical Institute, Children's Hospital, Boston, MA 02115.

Address reprint requests to Dr. Feldman, Hunterian 405, Division of Cardiology, The Johns Hopkins Hospital, Baltimore, MD 21205.

Received for publication 7 May 1987 and in revised form 30 December 1987.

J. Clin. Invest.

(c) The American Society for Clinical Investigation, Inc.

0021-9738/88/07/0189/09 \$2.00

Volume 82, July 1988, 189-197 of $\mathrm{G}_{\mathbf{s}}$ and catalytic adenylate cyclase, respectively, have failed to demonstrate abnormal function of $\mathrm{G}_{\mathrm{s}}$ or catalytic adenylate cyclase (6). We postulated that altered levels of other $G$ proteins, such as $G_{i}$, may contribute to the diminished function of the receptor-adenylate cyclase system in heart failure. $G_{\mathrm{i}}$ mediates the action of inhibitory hormones and neurotransmitters on the adenylate cyclase system $(5,7)$; therefore, altered activity could affect the transduction of transmembrane signals in the failing heart. The $G$ proteins share a common subunit structure: an $\alpha$ subunit which confers identity and a common dimeric, $\beta \gamma$ subunit (5). Inasmuch as the $\beta \gamma$ subunit of $G_{i}$ appears to mediate inhibition of the $G_{3}$ effects on adenylate cyclase $(8,9)$, increased levels of $G_{i}$ or a related $G$ protein may alter $\beta$-adrenergic receptor-adenylate cyclase coupling via changes in concentrations of the $\beta \gamma$ subunit. The bacterial exotoxins choleragen $(10,11)$ and pertussis toxin $(12,13)$ catalyze a reaction in which an ADP-ribose is transferred from NAD to specific amino acid acceptors on $\alpha G_{s}$ or $\alpha G_{i}$, respectively. Utilizing radiolabeled ADP ribose and these selective bacterial toxins, $G$ protein acceptors can be quantified. We measured levels of $G_{i}$ and $G_{s}$ in normal and failing human hearts using pertussis toxin- or choleragen-dependent ADP ribosylation. We also assayed activity of $\mathrm{G}_{\mathrm{s}}$ in an in vitro complementation assay using membranes prepared from murine S49 lymphoma cells that are genetically deficient in $\alpha \mathrm{G}_{\mathrm{s}}$.

\section{Methods}

Procurement of human cardiac tissue. Hearts with severe biventricular failure due to idiopathic dilated cardiomyopathy were obtained from The Johns Hopkins Hospital and Utah Cardiac Transplant programs at the time of cardiectomy for cardiac transplantation. These samples were obtained from nine males and two females with ages from 15 to 58 years (median $38 \mathrm{yr}$ ). Patients with ischemic cardiomyopathy were excluded using electrocardiograms, historical criteria, and coronary angiograms. In addition, reversible causes of cardiomyopathy including thyrotoxicosis, connective tissue disease, and hemochromatosis were excluded by appropriate clinical testing and endomyocardial biopsy. All patients were receiving conventional medical therapy that included digoxin, diuretics, and vasodilators. None received intravenous inotropic support or experimental oral inotropes before transplantation; however, one patient was also receiving oral enoximone, a phosphodiesterase inhibitor. Hemodynamic data (mean \pm SEM) for the patients with cardiac failure were the following: pulmonary wedge pressure $27 \pm 2.1 \mathrm{mmHg}$, cardiac index $1.8 \pm 0.1 \mathrm{liter} / \mathrm{min} \cdot \mathrm{m}^{2}$, and left ventricular ejection fraction of $13.8 \pm 1.1 \%$.

Nonfailing (control) hearts were obtained from organ donors whose hearts were not utilized for transplantation owing to the unavailability of suitable recipients despite multiple attempts to place the heart using the United Network for Organ Sharing $(n=8)$ or because of age $>50 \mathrm{yr}(n=3)$. The age of these organ donors ranged from 10 to $61 \mathrm{yr}$, with a median of $32 \mathrm{yr}$. Four of these subjects required no intravenous catecholamines prior to organ harvest, while five donors 
received dopamine $(2-4 \mu \mathrm{g} / \mathrm{kg} \cdot \mathrm{min})$ for $2-12 \mathrm{~h}$ before organ harvest in order to maintain adequate renal perfusion. Two other subjects received larger doses of dopamine $(12 \mu \mathrm{g} / \mathrm{kg} \cdot \min$ for $12 \mathrm{~h}$ and 8 $\mu \mathrm{g} / \mathrm{kg} \cdot \min$ for $28 \mathrm{~h}$, respectively) before organ harvest. An echocardiogram used to screen cardiac donors revealed normal left ventricular size and contractility (percent fraction of shortening $>25 \%$ ) in eight of the nine donors in whom the test was performed. The ninth donor had mild generalized left ventricular hypokinesis, whereas the final two donors had no history of cardiac disease, normal cardiac examination, and a normal chest roentgenogram. Oral and written informed consent for organ donation for transplantation or research purposes was obtained before cardiectomy (1). The excised hearts were immediately placed in ice-cold physiologic buffer and transported to the laboratory. The time between cross-clamp and tissue homogenization was $30 \mathrm{~min}$. For one heart which was procured off-site, the cold ischemic time was $<2 \mathrm{~h}$.

Cardiac membrane preparation. Approximately $3-5 \mathrm{~g}$ of the left ventricular free wall was excised and prepared as previously described $(1,14)$. The epicardium and endocardium were rapidly stripped and the tissue was minced in $5 \mathrm{vol}$ of ice-cold buffer containing $5 \mathrm{mM}$ Tris-Cl, pH 7.4, $250 \mathrm{mM}$ sucrose, and $1 \mathrm{mM}$ EGTA. The tissue was then homogenized with a Polytron (Brinkman Instruments Co., Westbury, NY) at full speed for $<5 \mathrm{~s}$ and centrifuged $(1,100 \mathrm{~g}$ for $20 \mathrm{~min})$ at $4^{\circ} \mathrm{C}$. The supernatant from this first centrifugation fraction was used for creatine kinase assays (1). The pellet was resuspended in the same buffer using a Potter-Elvejehm homogenizer and the pellet was washed three times. The final membrane fraction was filtered through sterile gauze and stored at $-70^{\circ} \mathrm{C}$. Storage for $6 \mathrm{mo}$ had no effect on the levels of $\alpha \mathrm{G}_{40}$ or $\alpha \mathrm{G}_{42-52}$ as assayed by bacterial toxin-dependent ADP ribosylation. Protein was measured (15) using bovine serum albumin as standard.

Another 5-g aliquot of left ventricular free wall was placed in icecold $10 \mathrm{mM}$ Tris-Cl-1 mM EGTA buffer ( $\mathrm{pH} \mathrm{8.0),} \mathrm{minced,} \mathrm{and} \mathrm{ho-}$ mogenized as previously described (3). This "crude membrane" fraction was washed and stored at $-70^{\circ} \mathrm{C}$ for use in receptor binding studies.

Pertussis toxin ADP ribosylation. $\mathrm{G}$ protein substrates of pertussis toxin were assayed using pertussis toxin-catalyzed incorporation of $\left[{ }^{32} \mathrm{P}\right] A D P-r i b o s e$ from $\left[{ }^{32} \mathrm{P}\right] \mathrm{NAD}(12,13)$. Membranes $(50 \mu \mathrm{g})$ were centrifuged $(15,000 \mathrm{~g}$ for $5 \mathrm{~min})$ and resuspended in $100 \mu \mathrm{l}$ of incubation buffer containing $100 \mathrm{mM}$ Tris-Cl, pH $8,6 \mathrm{mM} \mathrm{MgCl}, 2 \mathrm{mM}$ GTP, $10 \mathrm{mM}$ thymidine, $2.5 \mathrm{mM}$ ATP, $10 \mathrm{mM}$ isoniazid, and $10 \mu \mathrm{M}$ $\left[{ }^{32} \mathrm{P}\right]$ NAD $(10 \mathrm{Ci} / \mathrm{mmol})$. Pertussis toxin was activated by dialyzing with $10 \mathrm{mM}$ Tris-Cl, $\mathrm{pH} 8.0$, for $1 \mathrm{~h}$ at $4^{\circ} \mathrm{C}$ and incubating in $100 \mathrm{mM}$ dithiothreitol for $30 \mathrm{~min}$ at room temperature. After addition of activated pertussis toxin $(2.5 \mu \mathrm{g})$, the membrane preparations were incubated for $90 \mathrm{~min}$ at $30^{\circ} \mathrm{C}$. The ADP ribosylation reactions were stopped by centrifugation at $15,000 \mathrm{~g}$ for $5 \mathrm{~min}$ and washing the pellet with ice-cold buffer containing $50 \mathrm{mM}$ Tris- $\mathrm{Cl}, \mathrm{pH} 8,5 \%$ sucrose, 6 $\mathrm{mM} \mathrm{MgCl} 2,1 \mathrm{mM}$ EDTA, and $1 \mathrm{mM}$ dithiothreitol. Human erythrocyte membranes (16) were ADP ribosylated concurrently in each experiment.

Cholera toxin ADP ribosylation. $\mathrm{G}$ protein substrates of cholera toxin were assayed using cholera toxin-catalyzed incorporation of $\left[{ }^{32} \mathrm{P}\right] A D P$-ribose from $\left[{ }^{32} \mathrm{P}\right] \mathrm{NAD}(10,11)$ in a method analogous to that utilized for pertussis toxin-dependent ADP ribosylation. Membranes $(\sim 100 \mu \mathrm{g})$ were centrifuged at $15,000 \mathrm{~g}$ for $5 \mathrm{~min}$ and resuspended in $100 \mu$ l of buffer (pH 7.0) containing $100 \mathrm{mM} \mathrm{KPO}_{4}, 2 \mathrm{mM}$ GTP, $2.5 \mathrm{mM}$ ATP, $20 \mathrm{mM}$ thymidine, $20 \mathrm{mM}$ arginine, $10 \mathrm{U}$ of aprotinin, and $10 \mu \mathrm{M}\left[{ }^{32} \mathrm{P}\right] \mathrm{NAD}(20 \mathrm{Ci} / \mathrm{mmol})$. Cholera toxin was activated by incubating in $100 \mathrm{mM}$ dithiothreitol for $30 \mathrm{~min}$ at $30^{\circ} \mathrm{C}$. After the addition of $5 \mu \mathrm{g}$ of activated cholera toxin, the membrane preparations were incubated for $90 \mathrm{~min}$ at $30^{\circ} \mathrm{C}$. Reactions were stopped by centrifugation at $15,000 \mathrm{~g}$ for $5 \mathrm{~min}$ and washing the pellet with ice-cold buffer containing $50 \mathrm{mM}$ Tris- $\mathrm{Cl}, \mathrm{pH} \mathrm{8,5 \%}$ sucrose, 6 $\mathrm{mM} \mathrm{MgCl} 2,1 \mathrm{mM}$ EDTA, and $1 \mathrm{mM}$ dithiothreitol. Membranes from human erythrocytes were radiolabeled concurrently in these experiments.
Protein electrophoresis and measurement of autoradiographic densities. The membrane pellets were resuspended in $50 \mu \mathrm{l}$ of a solution containing $62.5 \mathrm{mM}$ Tris-Cl, pH 6.8, 2\% SDS, $10 \%$ glycerol, and 5\% $\beta$-mercaptoethanol and loaded into the wells of a 7.5\% SDS-polyacrylamide gel for electrophoresis (17). Gels were dried on cellophane and exposed Kodak XAR-5 film with an intensifying screen at $-70^{\circ} \mathrm{C}$ for 4 d. The signal intensity of the appropriate bands on the autoradiogram was analyzed using a two-dimensional densitometer (Loates, Westminister, MD) (18). It was technically difficult to apply the same amount of protein in each lane of the gels; therefore, these autoradiographic measurements were corrected for total protein in each lane by utilizing Coomassie Blue-stained proteins on the same gels. The amount of protein in four randomly selected Coomassie Blue-stained protein bands with approximate molecular weights of 126,000,57,000, 52,000 , and 38,000 was quantified using two-dimensional transmission densitometry. These bands were chosen because there was minimal surrounding Coomassie Blue-stained material and because the concentrations of these proteins was the same in cardiac membranes from control and failing hearts (data not shown). The interlane density ratios of these bands allowed correction for total protein in each lane. Because the density of the 40,000 -mol wt band on autoradiographics varied in different experiments owing to variations in the film exposure time and specific activity of the ${ }^{32}$ P]NAD, we standardized autoradiographic densities obtained from separate experiments by including membranes from at least three nonfailing hearts in each experiment. The levels of the ADP-ribosylated proteins in membranes from failing hearts was then calculated as a percentage of the mean of the nonfailing controls. This method of comparing $G$ protein levels in the same tissue from different individuals has been used extensively by others (19-21). Each membrane preparation was assayed in two or more separate experiments and the values reported are the average of these replicates. Statistical comparisons were performed using a nonpaired $t$ test (22).

Reconstitution assay of $G_{s}$ activity. We also assayed $\mathrm{G}_{\mathrm{s}}$ by measuring the ability of $G$ proteins extracted from cardiac membranes in detergent to complement the genetic $\mathrm{G}_{\mathbf{3}}$ deficiency of murine $\mathrm{S} 49 \mathrm{cyc} \mathrm{c}^{-}$ membranes (23) in vitro utilizing a modification of previously described techniques $(24,25)$. S49 $c y c^{-}$mouse lymphoma cells were propagated in Dulbecco's modified Eagle's medium containing $10 \%$ heat-inactivated horse serum (26). Plasma membranes were prepared by the method of Johnson and Bourne (27) utilizing a nitrogen disruption apparatus (Parr Instrument Co., Moline, IL) to disrupt the cells by nitrogen cavitation and sucrose density-gradient separation to purify the membranes.

The reconstitution assay was a modification of that described by Levine et al. (28). Cardiac membranes were incubated at $38^{\circ} \mathrm{C}$ for 30 min and pellets were then prepared by centrifugation at $15,000 \mathrm{~g}$ for 5 $\mathrm{min}$ at room temperature. The pellets were solubilized in buffer $(2.5$ $\mathrm{mg} / \mathrm{ml}$ ) containing $10 \mathrm{mM}$ Tris- $\mathrm{Cl}$ (pH 7.5), $10 \mathrm{mM} \mathrm{MgCl}, 0.1 \mathrm{mM}$ EDTA, $1 \mathrm{mM}$ dithiothreitol, and $0.2 \%$ (wt/vol) Lubrol PX for $60 \mathrm{~min}$ at room temperature. After centrifugation at $15,000 \mathrm{~g}$ for $15 \mathrm{~min}$ at room temperature, the supernatant (membrane extract) was removed and utilized immediately for assay of $\mathrm{G}$ protein activity. $\mathrm{Cyc}^{-}$membranes $(40 \mu \mathrm{g})$ and cardiac membrane extract $(15 \mu \mathrm{l})$ were incubated for $20 \mathrm{~min}$ at $30^{\circ} \mathrm{C}$ in buffer containing $50 \mathrm{mM}$ Hepes, $\mathrm{pH} 7.4,10 \mathrm{mM}$ $\mathrm{MgCl}_{2}, 0.3 \mathrm{mM} \mathrm{KCl}, 20 \mu \mathrm{M}$ cyclic AMP, $0.1 \mathrm{mM}$ dithiothreitol, $5 \mathrm{mM}$ creatine phosphate, $2.8 \mathrm{U}$ creatine phosphokinase, and the appropriate agonists in a total volume of $90 \mu \mathrm{l}$. After the 20 -min incubation, $10 \mu \mathrm{l}$ of buffer containing $\left[\alpha{ }^{32} \mathrm{P}\right] \mathrm{ATP}(0.1 \mathrm{Ci} / \mathrm{mmol})$ was added and the incubation was continued for $40 \mathrm{~min}$ at $30^{\circ} \mathrm{C}$. The reaction was terminated by adding $100 \mu \mathrm{l}$ of cold $50 \mathrm{mM}$ Hepes buffer, $\mathrm{pH} 7.5$, containing $2 \mathrm{mM}$ ATP, $0.5 \mathrm{mM}\left[{ }^{3} \mathrm{H}\right]$ cyclic AMP $(0.8 \mathrm{Ci} / \mathrm{mol})$, and $2 \%$ SDS and heating the mixture to $95^{\circ} \mathrm{C}$ for $3 \mathrm{~min}$. The $\left.{ }^{32} \mathrm{P}\right]$ cyclic AMP synthesized during the incubation was fractionated using Dowex-alumina chromatography (Dow Chemical Co., Midland, MI) (29). Cardiac membrane extracts demonstrated a small amount of adenylate cyclase activity in response to stimulators. Therefore this activity was subtracted from the activity of combined cardiac extract and $c y c^{-}$ membranes to obtain the increment due to the addition of $G_{\mathrm{s}}$. The 
intrinsic adenylate cyclase activity in the $c y c^{-}$membranes in the presence of isoproterenol plus 5'-guanylyl imidodiphosphate (Gpp(NH)p) ${ }^{1}$ or forskolin was negligible. Preliminary studies demonstrated that the amount of cyclic AMP formed in the assay reaction tube was dependent upon the amount of added extract and this relationship was linear over a range of 5-30 $\mu \mathrm{l}$ of extract. Therefore, all assays utilized $15 \mu \mathrm{l}$ of extract. The total amount of protein and detergent in these preliminary studies was kept constant by supplementing the reaction mixtures with cardiac membrane extracts which had been heated to $90^{\circ} \mathrm{C}$ for $10 \mathrm{~min}$ to inactivate the $\mathrm{G}$ proteins. As the data reported in the present study was acquired utilizing $c y c^{-}$membranes harvested at the same time, values are reported as the mean picomoles cyclic AMP produced \pm SEM for duplicate determinations. Cyclic AMP production was linear over the 40-min incubation period.

Adenylate cyclase assay. Adenylate cyclase activity was measured as previously described $(1,14)$. Briefly, cardiac membranes were incubated in a reaction mixture $(100 \mu \mathrm{l})$ that contained $50 \mathrm{mM}$ Hepes buffer (pH 7.4), $0.5 \mathrm{mM} \mathrm{MgCl}_{2}, 0.3 \mathrm{mM} \mathrm{KCl}, 20 \mu \mathrm{M}$ cyclic AMP, 0.1 $\mathrm{mM}$ dithiothreitol, $5 \mathrm{mM}$ creatine phosphate, $2.8 \mathrm{U}$ creatine phosphokinase, $0.1 \mathrm{mM}\left[\alpha{ }^{32} \mathrm{P}\right] \mathrm{ATP}(0.1-0.2 \mathrm{Ci} / \mathrm{mmol})$, and $1 \mu \mathrm{M}$ L-propranalol. The reaction mixture was prepared at $4^{\circ} \mathrm{C}$ with agonists added as indicated. Reactions were terminated by adding cold $50 \mathrm{mM}$ Hepes$\mathrm{Na}, \mathrm{pH} 7.5$, containing $2 \mathrm{mM}$ ATP, $0.5 \mathrm{mM}\left[{ }^{3} \mathrm{H}\right]$ cyclic AMP $(0.8$ $\mathrm{Ci} / \mathrm{mol})$, and $2 \% \operatorname{SDS}(100 \mu \mathrm{l})$ and heating the mixture to $95^{\circ} \mathrm{C}$ for 3 $\mathrm{min}$. The $\left[{ }^{32} \mathrm{P}\right]$ cyclic AMP synthesized during the incubation was fractionated using Dowex-alumina chromatography (29). Recovery of cyclic AMP was 70-85\%.

$\beta$-Adrenergic receptor binding. $\beta$-Receptor density was measured by [ ${ }^{125}$ I] iodocyanopindolol (ICYP) binding, as previously described (3, 6). Briefly, $40-150 \mu \mathrm{g} / \mathrm{ml}$ of crude membranes was incubated at $30^{\circ} \mathrm{C}$ for $2 \mathrm{~h}$ with increasing doses of ICYP (3-150 pM). Specific binding was defined as that displaced by $1 \mu \mathrm{M}$ L-propranolol, and the binding parameters $B_{\max }$ and $K_{\mathrm{D}}$ were determined by nonlinear least-squared fitting as previously described (3).

Creatine kinase. Creatine kinase was measured in the $1,100 \mathrm{~g}$ supernatants by a spectrophotometric technique used previously (1).

Materials. Pertussis toxin was obtained from List Biological Laboratories (Campbell, CA); cholera toxin from Sigma Chemical Co. (St. Louis, MO); $\left.{ }^{32} \mathrm{P}\right]$ NAD (1000 Ci/mmol) from New England Nuclear (Boston, MA); $\left[\alpha{ }^{32} \mathrm{P}\right]$ ATP $(561 \mathrm{Ci} / \mathrm{mmol})$ from ICN Biochemicals (Irvine, CA); [ $\left.{ }^{125} \mathrm{I}\right]$ iodocyanopindolol from Amersham Corp. (Arlington Heights, IL); molecular weight standards from Pharmacia, Inc. (Piscataway, NJ); Gpp(NH)p from Boehringer-Mannheim (Mannheim, Federal Republic of Germany); and all other reagents were the highest purity available commercially. Propranolol was a gift from Ayerst Laboratory (New York).

\section{Results}

Pertussis-catalyzed $\left[{ }^{32} P\right] A D P$ ribosylation. Pertussis toxin catalyzed the incorporation of $\left[{ }^{32} \mathrm{P}\right] \mathrm{ADP}$-ribose into one major peptide band $\left(\alpha \mathrm{G}_{40}\right)$. This radiolabeling was time dependent and maximal by 90 min (Fig. 1). Additionally, when membranes treated for 90 min were washed and then reincubated with fresh $\left.{ }^{32} \mathrm{P}\right] N A D$ and pertussis toxin, more radiolabel was not incorporated into $\alpha \mathrm{G}_{40}$ (Fig. 1). Therefore, under our assay conditions all pertussis toxin-dependent ADP-ribosylation sites on $\alpha \mathrm{G}_{40}$ were radiolabeled. The assay of $\alpha \mathrm{G}_{40}$ by ADP ribosylation was linear over a range of 10-125 $\mu \mathrm{g}$ of membrane protein (Fig. 2) and reproducible from experiment to experiment $( \pm 10 \%)$. No significant radiolabeling was incorporated when activated pertussis toxin was deleted from the incubation (results not shown).

1. Abbreviations used in this paper: Gpp(NH)p, 5-guanylyl imidodiphosphate; ICYP, $\left[{ }^{125} \mathrm{I}\right]$ iodocyanopindolol.

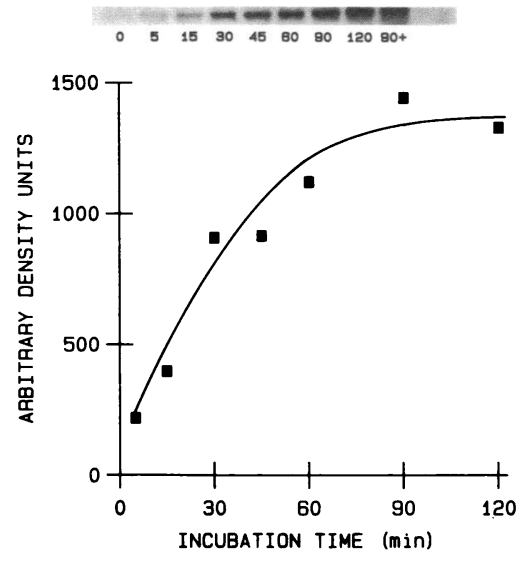

Figure 1. Time course of pertussis toxin-mediated ADP ribosylation of normal human cardiac 40,000-mol wt peptide. Activated pertussis toxin was incubated for varying times with human cardiac membranes before electrophoretic separation on SDS-polyacrylamide gels. Autoradiography of the 40,000-mol wt peptide is shown above. Some membranes were washed and reincubated for an additional 90 min with fresh pertussis toxin and $\left.{ }^{32} \mathrm{P}\right]$ NAD after $90 \mathrm{~min}(90+)$. The last lane shows absence of endogenous ADP ribosylation (90-min incubation without pertussis toxin). Two-dimensional densitometric measurements of the autoradiographic bands is given in arbitrary density units (OD $\times$ area).

The amount of [ $\left.{ }^{32} \mathrm{P}\right] \mathrm{ADP}$-ribose incorporated by pertussis toxin into $\alpha \mathrm{G}_{40}$ was significantly greater $(P<0.001)$ in membranes from failing human hearts than in controls. Relative to $\alpha \mathrm{G}_{40}$ levels in membranes of nine nonfailing hearts, $\alpha \mathrm{G}_{40}$ levels in eight failing hearts were $36 \pm 3 \%$ (mean \pm SEM) higher (Fig. 3). In addition, a second peptide ( $42,000 \mathrm{~mol} \mathrm{wt}$ ) was also radiolabeled but to a lesser degree. In contrast to results with the 40,000-mol wt peptide, levels of this peptide were similar in membranes from failing ( $112 \pm 6 \%$, mean \pm SEM) and nonfailing $(97 \pm 7 \%)$ hearts. It is unlikely that the 40,000 -mol wt peptide is a proteolytic fragment of the 42,000 -mol wt peptide inasmuch as one-dimensional, partial digestion (30) of these two radiolabeled proteins with trypsin or Staphylococcus aureus V8 protease revealed different proteolytic patterns (results not shown). Additionally, the 40,000- but not the 42,000 -mol wt peptide comigrates with the peptide that is ADP ribosylated in human erythrocytes (Fig. 4).

Cholera toxin-catalyzed $\left[^{32} \mathrm{P}\right] \mathrm{ADP}$ ribosylation and $\mathrm{Cyc}^{-}$ reconstitution assay of $G_{s} . G_{s}$ activity in cardiac membranes was measured by two independent methods: $(a)$ cholera toxin-

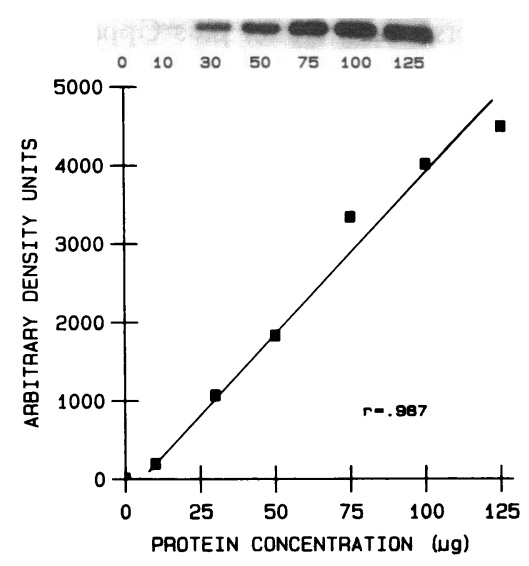

Figure 2. Linear relationship between protein concentration and maximal pertussis toxin-mediated ADP ribosylation. Varying amounts of membranes from normal human heart were incubated with activated pertussis toxin for $90 \mathrm{~min}$ and then electrophoretically separated on SDS-polyacrylamide gels. Autoradiography of the 40,000-mol wt ADP-ribosylated peptide is

shown above. Two-dimensional densitometric measurements of the autoradiographic bands is plotted using arbitrary density units (OD $X$ area). 

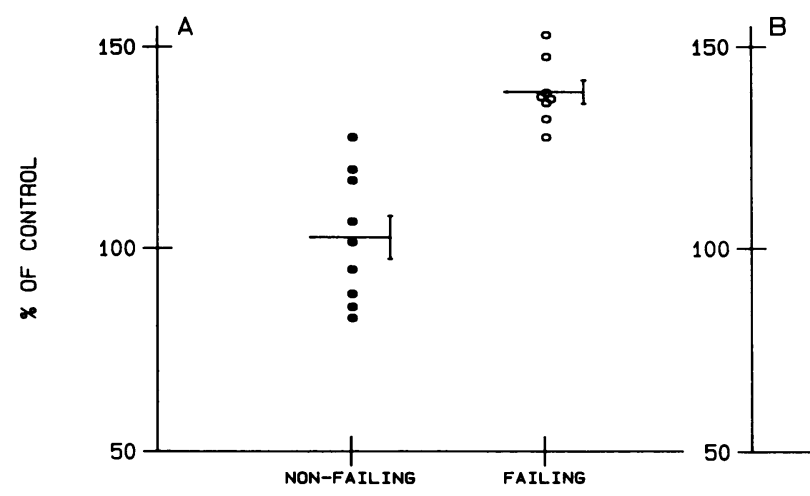

Figure 3. ADP ribosylation of the 40,000-mol wt peptide $(A)$ or 42,000-mol wt peptide $(B)$ in cardiac membranes from nonfailing and failing human hearts. Values are expressed as percent of the mean of three normal control samples on each autoradiograph. Each point represents one heart and is the average of at least two separate determinations. Horizontal bars represent the mean \pm SEM. There was a significant $(P$ $<0.001$ ) difference between 40,000-mol wt substrate levels in nonfailing and failing hearts. dependent ADP ribosylation of $\mathrm{G}$ proteins and $(b)$ the ability of detergent extracts to reconstitute adenylate cyclase activity in murine $\mathrm{S} 49 \mathrm{cyc} \mathrm{c}^{-}$lymphoma cell membranes. Cholera toxin catalyzed the incorporation of $\left[{ }^{32} \mathrm{P}\right] \mathrm{ADP}$-ribose into 45,000and $51,000-\mathrm{mol}$ wt peptides. The $45,000-\left(\alpha \mathrm{G}_{45}\right)$ but not the 51,000 -mol wt peptide $\left(\alpha \mathrm{G}_{51}\right)$ comigrates with the major ADP-ribosylated peptide in human erythrocytes (Fig. 5). As was seen with pertussis toxin-mediated ADP ribosylation, cholera toxin-dependent radiolabeling was time dependent and maximal by 90 min (Fig. 6), and washing the membranes and subsequent reincubation with fresh $\left[{ }^{32}\right.$ P]NAD and cholera toxin did not augment the incorporation of radiolabel into $\alpha \mathrm{G}_{45}$. Similar results were demonstrated for $\alpha \mathrm{G}_{51}$ (results not shown). Therefore, all cholera toxin-dependent ADP-ribosylation sites on the $G$ substrates were radiolabeled. Furthermore, the assay of $\alpha \mathrm{G}_{45}$ (Fig. 7) and $\alpha \mathrm{G}_{51}$ (results not shown) by ADP ribosylation was linear over a range of 50-200 $\mu \mathrm{g}$ of membrane protein and reproducible $( \pm 10 \%)$.

The cholera toxin-mediated incorporation of $\left[{ }^{32} \mathrm{P}\right] \mathrm{ADP}$ ribose into the $\alpha \mathrm{G}_{45}$ was not different in membranes from failing human heart when compared with nonfailing controls (Fig. 8). Furthermore, levels of the 51,000-mol wt peptide were similar in membranes from failing $(117.3 \pm 6.0 \%$, mean \pm SEM, $n=6)$ and nonfailing hearts $(99.6 \pm 11.0 \%, n=6)$. These results were confirmed by the fact that membrane extract from failing hearts did not differ from nonfailing hearts in its ability to reconstitute adenylate cyclase activity in $c y c^{-}$membranes in the presence of the activators isoproterenol plus $\mathrm{Gpp}(\mathrm{NH}) \mathrm{p}$ with or without the catalytic unit agonist forskolin (Fig. 8).

Adenylate cyclase assay. To determine the functional significance of alterations in $\mathrm{G}$ protein levels, we measured ade-

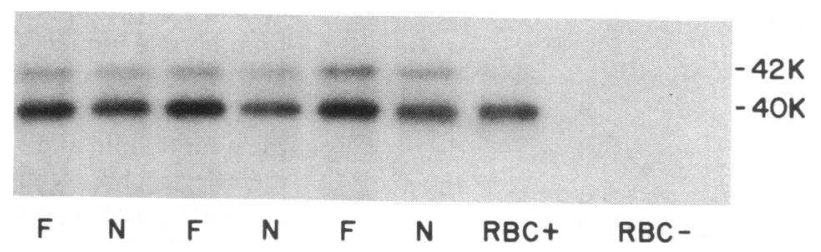

Figure 4. Autoradiograph of pertussis toxin-mediated ADP ribosylation of 40,000- and 42,000-mol wt peptides in cardiac membranes from three nonfailing $(N)$ and three failing $(F)$ human hearts. Erythrocyte membranes from a normal human control were incubated with $(R B C+)$ and without $(R B C-)$ pertussis toxin. Molecular weight standards shown in thousands $(\mathrm{K})$ at right. nylate cyclase activity in failing and nonfailing myocardium (Table I). ( - Propranolol $(1 \mu \mathrm{M})$ was included in the assay reactions to block any effects of endogenous catecholamines. Under these conditions, basal adenylate cyclase activity was reduced by $34 \%$ in the particulate fractions derived from failing left ventricles $(P<0.05)$ when compared with the nonfailing controls. Similarly, the response of adenylate cyclase to $10^{-4} \mathrm{M} \mathrm{Gpp}(\mathrm{NH}) \mathrm{p}$, a nonhydrolyzable GTP analogue, was also reduced significantly $(P<0.05)$ in preparations derived from failing hearts. Net stimulation by $\mathrm{Gpp}(\mathrm{NH}) \mathrm{p}$ (stimulation with agonist minus basal activity) was also reduced by $28 \%(P<0.05)$ in preparations derived from failing heart. Furthermore, forskolin-stimulated adenylate cyclase activity was lower in membranes from failing hearts in the presence of low concentrations (endogenous) of guanyl nucleotides (Table II) when compared with nonfailing controls. In contrast, stimulation by $10 \mathrm{mM}$ fluoride was not significantly different in the two groups, in that the net stimulation in the failing group was $93 \%$ of the stimulation encountered in preparations derived from nonfailing hearts.

In a separate experiment, membranes from failing and nonfailing hearts were incubated for $90 \mathrm{~min}$ at $37^{\circ} \mathrm{C}$ in the presence of either activated or heart-inactivated pertussis toxin under the conditions described for the ADP ribosylation reaction. Basal adenylate cyclase activity, as well as that stimulated by forskolin and $\mathrm{Gpp}(\mathrm{NH}) \mathrm{p}$, was significantly lower in the membranes from failing heart than in membranes from nonfailing controls (Table III). By contrast, basal and activated adenylate cyclase activity was the same in membranes from failing and nonfailing human heart after pertussis toxin treatment. The reduction in basal adenylate cyclase during the incubation results from heat lability of the catalytic subunit of adenylate cyclase; however, a 90-min labeling period was required for maximal ADP ribosylation (Fig. 1).

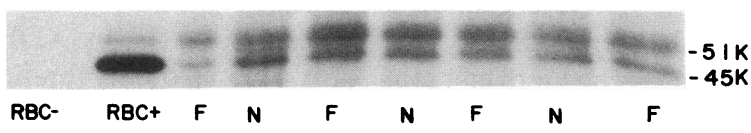

Figure 5. Representative autoradiograph of cholera toxin-mediated ADP ribosylation of 45,000- and 51,000-mol wt peptides in cardiac membranes from nonfailing $(N)$ and failing $(F)$ human hearts. Erythrocyte membranes from a normal human control were incubated with $(R B C+)$ and without $(R B C-)$ cholera toxin. Molecular weight standards shown in thousands $(\mathrm{K})$ at right. 


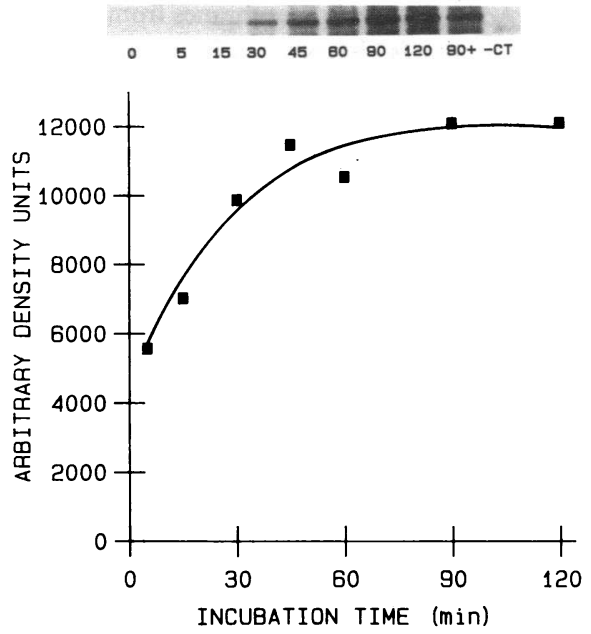

Figure 6. Time course of cholera toxin-mediated ADP ribosylation of normal human 45,000-mol wt peptide. Activated cholera toxin was incubated for varying times with human cardiac membranes before electrophoretic separation in SDS-polyacrylamide gels. Autoradiography of the $45,000 \mathrm{~mol}$ wt peptide is shown above. Some membranes were washed and reincubated for an additional $90 \mathrm{~min}$ with fresh cholera toxin and $\left[{ }^{32} \mathrm{P}\right] \mathrm{NAD}$ after $90 \mathrm{~min}(90+)$. The last lane $(-C T)$ shows absence of endogenous ADP ribosylation of the 45,000-mol wt peptide ( 90 -min incubation without cholera toxin). Two-dimensional densitometric measurements of the autoradiographic bands is given in arbitrary density units (OD $\times$ area).

$\beta$-Adrenergic receptor, creatine kinase measurements. As shown in Table IV, maximum ICYP binding was markedly reduced in crude membrane fractions derived from failing human left ventricles; the $B_{\max }$ value was decreased by $53 \%$ when compared with nonfailing preparations. In contrast, ICYP-receptor dissociation constants were not significantly different in failing and nonfailing heart preparations. Similarly, creatine kinase enzymatic activity, a marker of viable myocardium, was not significantly different in soluble fractions derived from failing and nonfailing ventricles (Table IV).

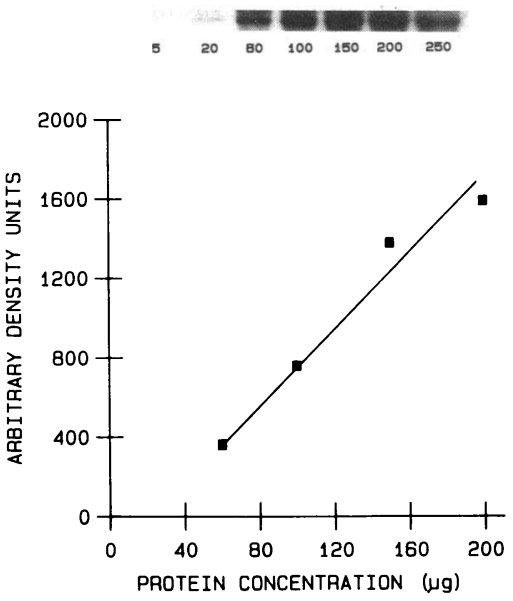

Figure 7. Linear relationship between protein concentration and cholera toxin-mediated ADP ribosylation of the 45,000-mol wt peptide. Varying amounts of membranes from normal hearts were incubated with activated cholera toxin for 90 min and then electrophoretically separated on SDS-polyacrylamide gels. Autoradiography of the 45,000-mol wt ADP-ribosylated peptide is shown above.

Two-dimensional densitometric measurements of the autoradiographic bands is plotted using arbitrary density units (OD $\times$ area).

\section{Discussion}

We have demonstrated that the level's of pertussis toxin substrate $\alpha \mathrm{G}_{40}$ is increased by $36 \%$ in failing human hearts when compared with nonfailing control hearts. By contrast, $\alpha \mathrm{G}_{\mathrm{s}}$ activity as measured by either cholera toxin-dependent ADP ribosylation or in vitro complementation assay was unchanged in the failing human heart. This alteration in $\alpha \mathrm{G}_{40}$ protein substrate was associated with a $30 \%$ decrease in basal and $\mathrm{Gpp}(\mathrm{NH}) \mathrm{p}$-stimulated adenylate cyclase activity. We found two cholera toxin substrates in particulate fractions of human heart. The presence of two cholera toxin substrates $(45,000$ and 52,000 mol wt) in cardiac and other tissue has been reported previously (10), and it has been shown that the two species are encoded by distinct mRNAs which arise from a single gene by internal alternative RNA splicing (31). However, the finding of two distinct radiolabeled peptide substrates for pertussis toxin-catalyzed ADP ribosylation in human cardiac membranes has not been previously demonstrated. The 40,000-mol wt radiolabeled peptide putatively represents a G protein in that it is a substrate for ADP ribosylation by pertussis toxin $(12,13)$ and comigrates with the 40,000 -mol wt pertussis toxin substrate of human erythrocytes. However, we cannot definitively identify this 40,000 -mol wt pertussis toxin substrate in heart as $\alpha \mathrm{G}_{i}$ because a closely related pertussis toxin substrate of $39,000 \mathrm{~mol} \mathrm{wt}\left(\alpha \mathrm{G}_{39}\right)$ has been demonstrated in several tissues including heart $(32,33)$. Because the physiologic role of $\alpha \mathrm{G}_{39}$ is unknown, there are no functional assays available to assess its activity in native membranes. The 40,000-mol wt peptide that we have described presumably represents $\alpha G_{i}$ as it comigrates with the pertussis toxin substrate in human erythrocytes which have not been shown to contain a 39,000-mol wt substrate. Furthermore, in most intact membranes only a 40,000-mol wt ADP ribosylated than the 39,000-mol peptide (34). However, more definitive assessments will be necessary. Immunoquantitative studies of $\alpha \mathrm{G}_{\mathrm{i}}$ and $\alpha \mathrm{G}_{39}$ are in progress in our laboratory; however, these may be difficult as at least three distinct species of $\alpha \mathrm{G}_{\mathrm{i}}(35)$ have recently been identified and antisera must be characterized as being selective for each of these three $\alpha \mathrm{G}_{i}$ species. Therefore, because the 40,000-mol wt peptide has not been definitively identified, we have chosen to refer to it as $\alpha \mathrm{G}_{40}$.

It is unlikely that the 40,000 -mol wt peptide is a proteolytic fragment of the 42,000-mol wt peptide since one-dimensional proteolytic mapping of the 42,000 - and 40,000 -mol wt peptides revealed different patterns. Furthermore, ${ }^{32} \mathrm{P}$ incorporation into the 42,000 -mol wt peptide by pertussis toxin was not different in failing and nonfailing human hearts, in contrast to the changes seen in the 40,000-mol wt peptide. Malbon et al. (36) have reported a second substrate for pertussis toxin-catalyzed ADP ribosylation in rabbit heart; however, this peptide was smaller $(40,000 \mathrm{~mol} \mathrm{wt})$ than $G_{i}(41,000 \mathrm{~mol} \mathrm{wt})$. This apparent discrepancy between his and our data may have resulted from differing electrophoresis conditions. When we used a $10 \%$ rather than a $7.5 \%$ polyacrylamide gel, a single 40,000-mol wt radiolabeled peptide band was observed (unpublished results). Human erythrocytes had much smaller amounts of the 42,000-mol wt peptide than did the cardiac membranes. The significance of these findings remains unclear.

Assay of $\alpha \mathrm{G}_{40}$ by ADP ribosylation has several limitations. First, ADP ribosylation measures only $\alpha$ subunit activity. With 

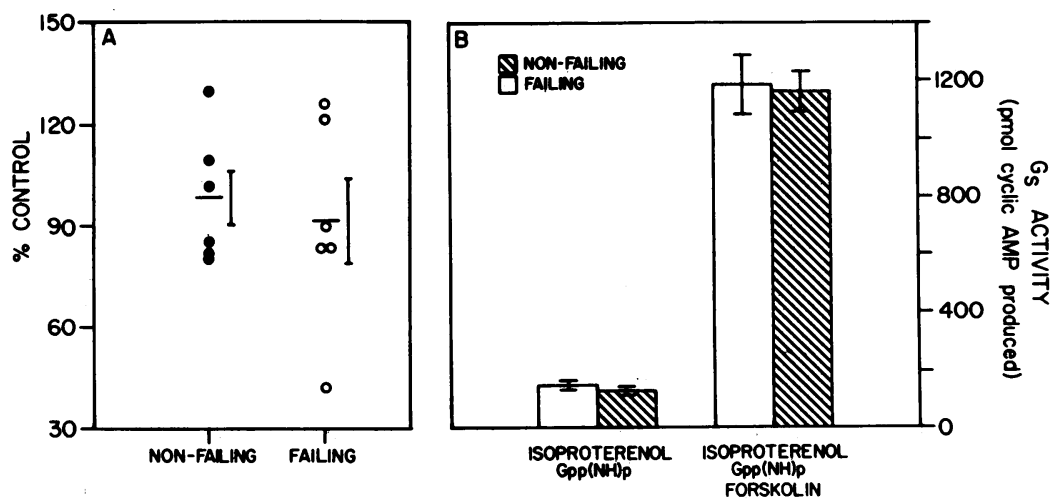

Figure 8. Activity of $\mathrm{G}_{8}$ in membranes from failing $(0)$ and nonfailing ( $\bullet$ ) human hearts as assessed by incorporation of $\left[{ }^{32} \mathrm{P}\right] \mathrm{ADP}$-ribose from $\left[{ }^{32} \mathrm{P}\right] \mathrm{NAD}$ into the 45,000-mol wt peptide subunit of $\mathrm{G}_{\mathrm{s}}(A)$ and the ability of detergent (Lubrol) extracts to complement adenylate cyclase in $G_{3}$-deficient $c y c^{-}$ S49 mouse lymphoma cells (B). Results in $A$ are normalized to three normal control samples on each autoradiograph as described in Methods. Each point represents one heart and is the average of at least two separate determinations. Horizontal bars represent the mean \pm SEM. Results in $B$ represent the picomoles of cyclic AMP synthesized $(\times 100)$ during a 40-min incubation in the presence of the indicated agonists as described in Methods $\left(10^{-5} \mathrm{M}\right.$ isoproterenol, $10^{-5} \mathrm{M}, \mathrm{Gpp}(\mathrm{NH}) \mathrm{p}, 10^{-5} \mathrm{M}$ forskolin). Values represent the mean $\pm S E M$ of determinations performed in duplicate. activation of a $\mathrm{G}$ protein, the $\alpha \mathrm{G}_{\mathrm{i}}-\mathrm{GTP}$ complex and $\beta \gamma$ subunit will be dissociated and the direct action of $\alpha G_{i}$ on adenylate cyclase may account for the diminished responsiveness of cardiac tissues to $\beta$-adrenergic agents. However, recent studies $(8,9)$ suggest that the free $\beta \gamma$ subunit of $G$ proteins rather than $\alpha G_{i}$ mediates inhibition of adenylate cyclase. Therefore, the concentration of $\beta \gamma$ may be as important in the overall physiologic response as the activity of $\alpha \mathrm{G}$. Finally, the recent demonstration that the $40,000-\mathrm{mol}$ wt subunit of $G$ protein designated $G_{K}$ (37) directly modulates atrial potassium channels suggests that increased cardiac $\alpha \mathrm{G}_{40}$ may alter cardiac function via mechanisms not directly affecting adenylate cyclase. A second limitation of ADP ribosylation is that it does not allow us to determine whether the absolute amount of $\alpha \mathrm{G}_{40}$ is increased or whether some $\alpha \mathrm{G}_{40}$ in normal heart membrane has been structurally or functionally altered so it is not ADP ribosylated by pertussis toxin. Electrophoretic migration of the radiolabeled $\alpha \mathrm{G}_{40}$ was identical in all samples, implying structural similarity; however, electrophoretic mobility is an insensitive measure of minor alterations in peptide structure. Therefore, further investigations will be needed to determine the functional significance and mechanism responsible for our study results.

The increase in $\alpha \mathrm{G}_{40}$ in failing human heart was associated with a decrease in basal and $\mathrm{Gpp}(\mathrm{NH}) \mathrm{p}$-stimulated adenylate cyclase activity but not in fluoride-stimulated activity. Fluoride appears to activate adenylate cyclase by enhancing the

Table I. Adenylate Cyclase Activity in Failing and Nonfailing Heart

\begin{tabular}{|c|c|c|c|c|c|}
\hline \multirow{2}{*}{$\begin{array}{l}\text { Group Gpp(NH)p } \\
\text { and }(n)\end{array}$} & \multirow[b]{2}{*}{ Basal } & \multicolumn{2}{|c|}{$\mathrm{NaF}$} & \multicolumn{2}{|c|}{ Gpp(NH)p } \\
\hline & & $10^{-2} \mathrm{M}$ & Net & $10^{-4} \mathrm{M}$ & Net \\
\hline & \multicolumn{5}{|c|}{ pmol cyclic $A M P / m i n \cdot m g$ protein } \\
\hline \multirow[t]{2}{*}{ 1. Nonfailing (9) } & 7.3 & 62.3 & 55.0 & 13.8 & 6.4 \\
\hline & \pm .6 & \pm 4.5 & \pm 4.1 & \pm 1.1 & \pm .8 \\
\hline \multirow[t]{2}{*}{ 2. Failing (11) } & $4.8^{*}$ & 55.8 & 51.0 & $9.4^{*}$ & $4.6^{*}$ \\
\hline & \pm .4 & \pm 2.9 & \pm 2.6 & \pm .7 & \pm .4 \\
\hline
\end{tabular}

Values given as mean $\pm \mathrm{SEM}$.

$* P<0.05$. interaction of the regulatory proteins with the catalytic unit without dissociating the $G$ protein into its subunits $(38,39)$. Inhibition of adenylate cyclase by $\mathrm{Gi}$ requires the dissociation of free $\beta \gamma$ subunits from $\alpha G_{i}$ and subsequent coupling of the free $\beta \gamma$ units with activated (dissociated) $\alpha \mathrm{G}_{\mathrm{s}}(40)$. Therefore, activation of $G_{s}$ by fluoride may be insensitive to changes in the inhibitory pathway. Further evidence that fluoride stimulates $\alpha \mathrm{G}_{\mathrm{s}}$ and has no action on $\mathrm{G}_{\mathrm{i}}$ is the finding that fluoride activation of adenylate cyclase is unaffected by inactivation of $G_{i}$ by pertussis toxin in model systems (40). Our data from the cholera toxin-catalyzed ADP ribosylation and fluoride stimulation of adenylate cyclase indicate that $\alpha \mathrm{G}_{\mathrm{s}}$ is not structurally or functionally compromised in the failing human heart.

By contrast, the reduced basal adenylate cyclase activity, the reduced maximal response to $\mathrm{Gpp}(\mathrm{NH}) \mathrm{p}$, and the enhanced inhibitory effect of $\mathrm{Gpp}(\mathrm{NH}) \mathrm{p}$ and low concentrations of GTP on forskolin-stimulated adenylate cyclase activity in the failing heart, coupled with normal functioning of $G_{s}$, suggest that there is increased functional activity of the inhibitory $G$ protein pathway in the failing heart. Unlike fluoride, $\mathrm{Gpp}(\mathrm{NH}) \mathrm{p}$ reversibly dissociates $\mathrm{G}$ proteins into its subunits (41), and $\mathrm{Gpp}(\mathrm{NH}) \mathrm{p}$-mediated activation of adenylate cyclase can be reversed by GTP, $\beta$ agonists, or adenosine, presumably by reassociation of $\alpha \mathrm{G}_{\mathrm{s}}$ with free $\beta \gamma$ subunits. Furthermore, both $G_{s}$ and $G_{i}$ can exist in an active undissociated $\mathrm{Gpp}(\mathrm{NH}) \mathrm{p}$-bound form (38). Therefore, activation of $\mathrm{G}$ proteins by $\mathrm{Gpp}(\mathrm{NH}) \mathrm{p}$ allows for expression of both the stimulatory and inhibitory $G$ pathways and the amount of adenylate cyclase stimulation is due to a net effect of both $\alpha \mathrm{G}_{i}$ and $\alpha \mathrm{G}_{\mathrm{s}}$ activity. Thus, the decrease in basal adenylate cyclase activity

Table II. Forskolin-stimulated Adenylate Cyclase Activity in Membranes Prepared from Failing and Nonfailing Human Heart

\begin{tabular}{lccc}
\hline & Nonfailing $(n=9)$ & Failing $(n=11)$ & $P$ \\
\hline \multicolumn{4}{c}{ pmol cyclic AMP/min $\cdot$ mg protein } \\
Basal & $9.47 \pm 0.8$ & $6.10 \pm 0.5$ & $<0.01$ \\
Forskolin $\left(10^{-4} \mathrm{M}\right)$ & $324.9 \pm 21.3$ & $234.9 \pm 17.2$ & $<0.01$ \\
Forskolin (net) & $315.3 \pm 20.7$ & $228.8 \pm 16.8$ & $<0.01$
\end{tabular}

Assay conditions were identical to those described in Methods. Values given as mean \pm SEM. 
Table III. Effect of Pertussis Toxin Pretreatment on Adenylate Cyclase Activity in Failing and Nonfailing Human Heart

\begin{tabular}{lccc}
\hline \multicolumn{1}{c}{ Conditions } & Pretreatment & \multicolumn{1}{c}{ Failing } & Nonfailing \\
\hline Basal & - & $1.02 \pm 0.01^{*}$ & $1.30 \pm 0.11$ \\
Basal & + & $1.38 \pm 0.5$ & $1.46 \pm 0.13$ \\
$\begin{array}{l}\text { Forskolin }\left(10^{-4} \mathrm{M}\right) \text { and } \\
\quad \mathrm{Gpp}(\mathrm{NH}) \mathrm{p}\left(10^{-5} \mathrm{M}\right)\end{array}$ & - & $35.4 \pm 2.5^{*}$ & $44.5 \pm 2.8$ \\
$\begin{array}{l}\text { Forskolin }\left(10^{-4} \mathrm{M}\right) \text { and } \\
\quad \mathrm{Gpp}(\mathrm{NH}) \mathrm{p}\left(10^{-5} \mathrm{M}\right)\end{array}$ & + & $52.9 \pm 4.2$ & $46.8 \pm 3.5$ \\
\hline
\end{tabular}

$(n=8)$, Cardiac membranes were incubated for $90 \mathrm{~min}$ at $38^{\circ} \mathrm{C}$ with pertussis toxin or heat-inactivated toxin (control) as described in Methods. At the conclusion of the incubation, the reaction was centrifuged at $15,000 \mathrm{~g}$ and the pellet resuspended in Tris-SucroseEGTA buffer. Adenylate cyclase activity was then measured as described in Methods.

${ }^{*} P<0.05$ comparing membranes from failing and nonfailing hearts.

and the diminished response to $G p p(N H) p$ in preparations derived from failing heart can be interpreted as representing an increase in inhibitory $G$ regulatory activity. That forskolinmediated stimulation of adenylate cyclase activity can be inhibited by guanyl nucleotides has been demonstrated in the human heart (6) as well as in other systems (42). Furthermore, recent studies (43) have suggested that this effect is mediated via $G_{i}$. Therefore, the present results imply that the function of the inhibitory pathway is increased in failing myocardium. If the inhibitory $G$ regulatory activity is increased, we would expect an alteration in the activity of the muscarinic receptor. In fact, recent studies have demonstrated tighter coupling of muscarinic receptors to adenylate cyclase inhibition in human heart membranes obtained from patients with idiopathic dilated cardiomyopathy when compared with nonfailing controls (44). Finally, the fact that both the decrease in basal adenylate cyclase activity and the enhanced inhibition of forskolin-stimulated activity by $\operatorname{Gpp}(\mathrm{NH}) \mathrm{p}$ disappears after inactivation of $G_{i}$ by pertussis toxin, implies the presence of an increase in inhibitory $G$ regulatory activity in failing human hearts.

Several previous studies $(1,3,6)$ have described a reduction in $\beta$-receptor density in the failing human heart that is similar to the reduction found in the current investigation. In this and previous studies, the fluoride-stimulated response of adenylate

Table IV. Comparison of $\beta$-Adrenergic Receptor Density and Creatine Kinase Activity in Failing and Nonfailing Human Heart

\begin{tabular}{cccc}
\hline & \multicolumn{2}{c}{ ICYP } & \\
\cline { 2 - 4 } Group & $B_{\max }$ & $K_{\mathrm{d}}$ & Creatine kinase \\
\hline$n$ & $f m o l / m g$ & $p M$ & $I U / g w w$ \\
Nonfailing (11) & 112.9 & 19.15 & 995 \\
& \pm 18.6 & \pm 4.21 & \pm 116 \\
Failing (9) & $52.7^{*}$ & 15.76 & 744 \\
& \pm 3.9 & \pm 5.22 & \pm 70
\end{tabular}

Data are given as mean \pm SEM.

$* P<0.05$ cyclase has been preserved in preparations derived from failing heart. However, in contrast to the present study, previous studies have not demonstrated a significant reduction of basal or forskolin-stimulated adenylate cyclase activity in failing hearts. The present study differed from previous studies in that propranalol was present in the incubation reactions, exogenous GTP was absent, and the sample size was larger. Therefore, it is likely that the statistically significant difference in basal and forskolin-stimulated activity noted in the present study was at least in part masked in previous studies by endogenous catecholamine stimulation of adenylate cyclase, or alternatively that non- $\beta$-adrenergic blocking properties of propranolol accounted for accentuation of small differences in basal adenylate cyclase activity. Creatine kinase activity was not significantly different in failing and nonfailing heart in our study. These results are consistent with previous studies in which enzymatic membrane markers (3), $\alpha_{1}$-receptor density (45), dihydropyridine receptor density (46), and histamine stimulation of adenylate cyclase (47) were found to be unchanged in failing human heart when compared with nonfailing controls. Therefore, the apparent increase in $\alpha \mathrm{G}_{40}$ activity demonstrated in the present study and the reduction in $\beta$-receptor density noted in this and previous studies $(1,3,6)$ are specific pharmacologic processes that appear to be unrelated to nonspecific effects of patient debilitation or tissue deterioration.

Pharmacologic effects of digitalis derivatives or diuretics on cardiac $G$ protein levels in the failing hearts cannot be excluded from our data. The finding that a 40,000 mol wt $\alpha \mathrm{G}$ may modulate transmembrane ion channels (37) makes such an effect of digitalis plausible. Unfortunately, current medical therapy for cardiac failure makes it unlikely that human tissue will become available to exclude this possibility. Finally, some nonfailing hearts were exposed to dopamine for varying lengths of time. The uniform $\alpha \mathrm{G}_{40}$ levels in the nonfailing hearts, despite marked differences in dosage and time of therapy with dopamine, make it unlikely that dopamine caused the effects found here.

Alterations in $\mathrm{G}$ protein levels have not been demonstrated previously in the failing human heart despite pharmacologic studies in vitro that have suggested a generalized abnormality in the receptor-G protein-adenylate cyclase complex proximal to the catalytic subunit $(4,6)$. Both $\beta$-adrenergic agonists and the phosphodiesterase inhibitor milrinone increase isometric tension in trabeculae carneae isolated from normal human hearts but not in trabeculae from failing hearts. By contrast, direct activation of the catalytic unit by forskolin effects similar increases in developed tension in both failing and nonfailing hearts. These results might be explained by decreased activity of $\alpha \mathrm{G}_{\mathrm{s}}$, increased levels of $\alpha \mathrm{G}_{\mathrm{i}}$, or increased activity of $\beta \gamma$ subunit of $\mathrm{G}$ proteins, any of which would decrease cyclic AMP generation in response to adrenergic agents and therefore diminish the contractile response to a phosphodiesterase inhibitor. Therefore, our results coupled with previous studies suggest that changes in the levels of $\alpha \mathrm{G}_{40}$ contributes to the altered regulation of adenylate cyclase in heart failure.

Altered $\mathrm{G}$ protein function has been described in human disease. Organ-specific alterations of a guanine nucleotidebinding regulatory protein can have pathophysiologic consequences in several acquired and genetic human diseases (48). Choleragen and pertussis toxin, the causative toxins for chol- 
era and whooping cough, respectively, exert their cellular effects by altering $G$ protein function in the gut or respiratory tract (49). Additionally, pseudohypoparathyroidism type Ia, a multihormone resistance syndrome, results from a heritable generalized deficiency of $\alpha \mathrm{G}_{\mathrm{s}}$ (19-21).

Our studies were performed at the terminal stage of heart failure. Therefore, we cannot ascertain whether increased levels of $\alpha \mathrm{G}_{40}$ are an acquired defect of pathophysiologic significance or a nonspecific response to myocardial failure or pharmacologic therapy. However, the evidence for increased $\alpha \mathrm{G}_{40}$ activity in the failing human heart implies that stimulation of cardiac muscle contraction by receptor pathways coupled to $G_{s}$ may be under tonic inhibition, or that inotropic stimulation by $\beta$-adrenergic mechanisms might be constrained not only by the reduction in $\beta$-receptor density that occurs in the failing heart but also by the increased degree of inhibition by receptor traffic coupled through $\alpha \mathrm{G}_{40}$. Thus, increased $\alpha \mathrm{G}_{40}$ activity is a new marker for failing myocardium and has implications for further understanding of the biochemistry of heart failure.

\section{Acknowledgments}

We thank Drs. James Burdick, Bruce A. Reitz, Nelson A. Burton, A Michael Borkon, and Timothy J. Gardner and June Murray, Randy Rasmussen, and Ellie Soltani for their contributions to this study. We are indebted to Jacqueline Warner for preparing the manuscript.

This work was supported in part by grants AM-36085 and HC-13108 from the National Institutes of Health, a Basil O'Connor starter grant from the March of Dimes (Dr. Van Dop) and the Otsuka Pharmaceutical Co. (Dr. Feldman). Dr. Hershberger is a Merck Cardiology Fellow. Dr. Feldman is the recipient of a Clinician Scientist Faculty Development Award from the Andrew W. Mellon Foundation.

\section{References}

1. Bristow, M. R., R. Ginsburg, W. A. Minobe, R. S. Cubicciotti, W. S. Sageman, K. Lurie, M. E. Billingham, D. C. Harrison, and E. B. Stinson. 1982. Decreased catecholamine sensitivity and $\beta$-adrenergic receptor density in failing human hearts. N. Engl. J. Med. 307:205211.

2. Fowler, M. B., J. A. Laser, G. L. Hopkins, W. Minobe, and M. R. Bristow. 1986. Progressive $\beta$-receptor down-regulation and specific pharmacologic subsensitivity to agonist response. Circulation. 74:1290-1302.

3. Bristow, M. R., R. Ginsburg, M. Fowler, W. Minobe, R. Rasmussen, P. Zera, R. Menlove, P. Shah, and E. Stinson. 1986. $\beta_{1}$ - and $\beta_{2}$-adrenergic receptor subpopulations in normal and failing human ventricular myocardium: coupling of both receptor subtypes to muscle contraction and selective $\beta_{1}$ receptor down-regulation in heart failure. Circ. Res. 59:297-308.

4. Feldman, M. D., L. Copelas, J. K. Gwathmey, P. Phillips, S. E. Warren, F. J. Schoen, W. Grossman, and J. P. Morgan. 1987. Deficient production of cyclic AMP: pharmacologic evidence of an important cause of contractile dysfunction in patients with end-stage heart failure. Circulation. 75:331-339.

5. Stryer, L., and H. R. Bourne. 1986. G proteins: a family of signal transducers. Annu. Rev. Cell. Biol. 2:391-419.

6. Bristow, M. R., R. Ginsburg, A. Strosberg, W. Montgomery, and W. Minobe. 1984. Pharmacology and inotropic potential of forskolin in the human heart. J. Clin. Invest. 74:212-223.

7. Hazeki, O., and M. Ui. 1981. Modification by islet-activating protein of receptor-mediated regulation cyclic AMP accumulating in isolated rat heart cells. J. Biol. Chem. 256:2856-2862.
8. Northup, J. K., P. C. Sternweis, and A. G. Gilman. 1983. The subunits of the stimulatory regulatory component of adenylate cyclase. J. Biol. Chem. 258:11361-11368.

9. Enomoto, K., and T. Asakawa. 1986. Inhibition of catalytic unit of adenylate cyclase and activation of GTPase of $N_{i}$ protein by $\beta \gamma$-subunits of GTP-binding proteins. FEBS (Fed. Eur. Biochem. Soc.) Lett. 202:63-68.

10. Johnson, G. L., H. R. Kaslow, and H. R. Bourne. 1978. Genetic evidence that cholera toxin substrates are regulatory components of adenylate cyclase. J. Biol. Chem. 253:7120-7123.

11. Gill, D. M., and R. Meren. 1978. ADP-ribosylation of membrane proteins catalyzed by cholera toxin: basis of the activation of adenylate cyclase. Proc. Natl. Acad. Sci. USA. 75:3050-3054.

12. Bokoch, G. M., T. Katada, J. K. Northup, E. L. Hewlett, and A. G. Gilman. 1983. Identification of the predominant substrate for ADP-ribosylation by islet activating protein. J. Biol. Chem. 258:2072-2075

13. Codina, J., J. Hildebrandt, R. Iyengar, L. Birnbaumer, R. D. Sekura, and C. R. Manclark. 1983. Pertussis toxin substrate, the putative $\mathrm{N}_{\mathrm{i}}$ component of adenylyl cyclases, is an $\alpha \beta$ heterotrimer regulated by guanine nucleotide and magnesium. Proc. Natl. Acad. Sci. USA. 80:4276-4280.

14. Feldman, A. M., M. A. Levine, K. L. Baughman, and C. Van Dop. 1987. $\mathrm{NAD}^{+}$-mediated stimulation of adenylate cyclase in cardiac membranes. Biochem. Biophys. Res. Commun. 142:631-637.

15. Lowry, O. H., N. J. Rosebrough, A. C. Farr, and R. J. Randall. 1951. Protein measurements with the folin phenol reagent. J. Biol. Chem. 193:265-275.

16. Hudson, T. H., and G. L. Johnson. 1980. Peptide mapping of adenylate cyclase regulatory proteins that are cholera toxin substrates. J. Biol. Chem. 255:7480-7486.

17. Laemmli, U. K. 1970. Cleavage of structural proteins during the assembly of the head of bacteriophage T4. Nature (Lond.). 227:680-685.

18. Unnerstall, J. R., D. L. Niehoff, M. J. Kuhar, and J. M. Palacios. 1982. Quantitative receptor autoradiography using $\left[{ }^{3} \mathrm{H}\right]$ Ultrofilm: application to multiple benzodiazepine receptors. $J$. Neurosci. Methods. 6:59-73.

19. Farfel, Z., A. S. Brickman, H. R. Kaslow, V. M. Brothers, and H. R. Bourne. 1980. Defect of receptor-cyclase coupling protein in pseuohypoparathyroidism. N. Engl. J. Med. 303:237-242.

20. Farfel, Z., V. M. Brothers, A. S. Brickman, F. Conte, R. Neer, and H. R. Bourne. 1981. Pseudohypoparathyroidism: inheritance of deficient receptor-cyclase coupling activity. Proc. Natl. Acad. Sci. USA. 78:3095-3102.

21. Downs, R. W., R. D. Sekura, M. A. Levine, and A. M. Spiegel. 1985. The inhibitory adenylate cyclase coupling protein in pseudohypoparathyroidism. J. Clin. Endocrinol. Metab. 61:351-354.

22. Snedecor, G. W., and W. G. Cochran. 1967. Statistical Methods. Sixth edition. The Iowa State University Press, Ames, Iowa.

23. Bourne, H. R., P. Cofino, and G. M. Tomkins. 1975. Selection of a variant lymphoma cell deficient in adenylate cyclase. Science (Wash. DC). 187:750-752.

24. Ross, E. M., A. C. Howlett, K. M. Ferguson, and A. G. Gilman. 1978. Reconstitution of hormone sensitive adenylate cyclase activity with resolved components of the enzyme. J. Biol. Chem. 253:64016412.

25. Nielsen, T. B., P. M. Lad, S. Preston, and M. Rodbell. 1980. Characteristics of the guanine nucleotide regulatory components of adenylate cyclase in human erythrocyte membranes. Biochim. Biophys. Acta. 629:143-155.

26. Coffino, P., H. R. Bourne, and G. M. Tomkins. 1974. Somatic genetic analysis of cyclic AMP action: selection of unresponsive mutants. J. Cell. Physiol. 85:603-610.

27. Johnson, G. L., and H. R. Bourne. 1977. Influence of cholera toxin on the regulation of adenylate cyclase by GTP. Biochem. Biophys. Res. Commun. 78:792-798.

28. Levine, M. A., C. Eil, R. W. Downs, and A. M. Spiegel. 1983. 
Deficient guanine nucleotide regulatory unit activity in cultured fibroblast membranes from patients with pseudohypoparathyroidism type I: A cause of impaired synthesis of $3^{\prime}, 5^{\prime}$-cyclic AMP by intact and broken cells. J. Clin. Invest. 72:316-324.

29. Salomon, Y. 1979. Adenylate cyclase assay. Adv. Cyclic Nucleotide Res. 10:35-55.

30. Cleveland, D. W. 1983. Peptide mapping in one dimension by limited proteolysis of sodium dodecyl sulfate-solubilized proteins. Methods Enzymol. 96:222-229.

31. Robishaw, J. D., M. D. Smigel, and A. G. Gilman. 1986. Molecular basis for two forms of the $G$ protein that stimulates adenylate cyclase. J. Biol. Chem. 261:9587-9590.

32. Sternweis, P. C., and J. D. Robishaw. 1984. Isolation of two proteins with high affinity for guanine nucleotides from membranes of bovine brain. J. Biol. Chem. 259:13806-13813.

33. Neer, E. J., J. M. Lok, and L. G. Wolf. 1984. Purification and properties of the inhibitory guanine nucleotide regulatory unit of brain adenylate cyclase. J. Biol. Chem. 259:14222-14229.

34. Huff, R. M., and E. J. Neer. 1986. Subunit interations of native and ADP-ribosylated $\alpha_{39}$ and $\alpha_{41}$, Two guanine nucleotide-binding proteins from bovine cerebral cortex. J. Biol. Chem. 261:1105-1110.

35. Jones, D. T., and R. R. Reed. 1987. Molecular cloning of five GTP-binding protein cDNA species from rat olfctory neuroephithelium. J. Biol. Chem. 262:14241-14249.

36. Malbon, C. C., T. J. Mangano, and D. C. Watkins. 1985. Heart contains two substrates $\left(M_{r}=40,000\right.$ and 41,000$)$ for pertussis toxincatalyzed ADP-ribosylation that co-purify with $\mathrm{N}_{\mathrm{s}}$. Biochem. Biophys. Res. Commun. 128:809-815.

37. Yatani, A., J. Codina, A. M. Brown, and L. Birnbaumer. 1987. Direct activation of mammalian atrial muscarinic potassium channels by GTP regulatory protein $\mathrm{G}_{\mathrm{k}}$. Science (Wash. DC). 235:207-211.

38. Codina, J., J. D. Hildebrandt, L. Birnbaumer, and R. D. Sekura. 1984. Effects of guanine nucleotides and $\mathrm{Mg}$ on human erythrocyte $\mathrm{N}_{\mathrm{i}}$ and $\mathrm{N}_{\mathrm{s}}$, the regulatory components of adenylyl cyclase. J. Biol. Chem. 259:11408-11418.

39. Downs, R. W., A. M. Spiegel, M. Singer, S. Reen, and G. D.
Aurbach. 1980. Fluoride stimulation of adenylate cyclase is dependent on the guanine nucleotide regulatory protein. J. Biol. Chem. 255:949954.

40. Katada, T., G. M. Bokoch, J. K. Northup, M. Ui, and A. G. Gilman. 1984. The inhibitory guanine nucleotide-binding regulatory component of adenylate cyclase: properties and function of the purified protein. J. Biol. Chem. 259:3568-3577.

41. Levitzki, A. 1987. Regulation of adenylate cyclase by hormones and G-proteins. FEBS (Fed. Eur. Biochem. Soc.) Lett. 211:113-118.

42. Skorecki, K. L., A. S. Verkman, and D. A. Ausiello. 1987. Cross talk between stimulatory and inhibitory guanosine 5'-triphosphate binding proteins: role in activation and desensitization of the adenylate cyclase response to vasopressin. Biochemistry. 26:639-645.

43. Gawler, D., G. Milligan, A. M. Spiegel, C. G. Unson, and M. D. Houslay. 1987. Abolition of the expression of inhibitory guanine nucleotide regulatory protein $\mathrm{G}_{\mathrm{i}}$ activity in diabetes. Nature (Lond.). 327:229-232.

44. Jacobsson, G., A. Hjalmarson, A. Waldenstrom, E. Varnauskas, and M. Jacoub. 1985. Abnormalities of adrenergic and muscarinic receptor control of human myocardial membranes in idiopathic dilated cardiomyopathy. J. Mol. Cell. Cardiol. 17(Suppl. 3):52.

45. Bristow, M. R., W. Minobe, and R. Rasmussen. 1985. Differential regulation of alpha and beta-adrenergic receptor in the failing human heart. Circulation. 72(Suppl III):1315. (Abstr.)

46. Rasmussen, R., W. Minobe, H. Marita, R. Ginsburg, and M. R. Bristow. 1987. Are calcium channels altered in the failing human heart? Circulation. 76(Suppl. IV):535. (Abstr.)

47. Kantrowitz, N. E., M. R. Bristow, W. A. Minobe, M. E. Billingham, and D. C. Harrison. 1982. Histamine-mediated myocardial damage in rabbits. J. Mol. Cell. Cardiol. 14:551-555.

48. Spiegel, A. M., P. Gierschik, M. A. Levine, and R. W. Downs. 1985. Clinical implications of guanine nucleotide-binding proteins as receptor-effect or couplers. N. Engl. J. Med. 312:26-33.

49. Moss, J., D. L. Burns, J. A. Hsia, E. L. Hewlett, R. L. Guerrant, and M. Vaughan. 1984. Cyclic nucleotides: Mediators of bacterial toxin action in disease. Ann. Intern. Med. 101:653-666. 